\title{
SLC7A7 wt Allele
}

National Cancer Institute

\section{Source}

National Cancer Institute. SLC7A7 wt Allele. NCI Thesaurus. Code C118996.

Human SLC7A7 wild-type allele is located in the vicinity of $14 q 11.2$ and is approximately

$57 \mathrm{~kb}$ in length. This allele, which encodes $\mathrm{y}+\mathrm{L}$ amino acid transporter 1 protein, is involved in cationic amino acid transport. Mutation of the gene is associated with lysinuric protein intolerance. 